\title{
PENGARUH AGENCY COST, RETURN ON EQUITY (ROE), DAN FREE CASH FLOWTERHADAP DIVIDEND PAYOUT RATIO PADA PERUSAHAAN MANUFAKTUR YANG TERDAFTAR DI BEI PERIODE 2010-2019
}

\author{
Siti Sarah Hasibuan', Lukmanul Hakim² \\ ${ }^{1 *}$ Fakultas Ekonomi dan Bisnis Universitas Teknologi Sumbawa \\ ${ }^{2}$ Fakultas Ekonomi dan Bisnis Universitas Teknologi Sumbawa
}

*Corresponding Author email: 1sitisarahhasibuan99@gmail.com, ${ }^{2}$ lukmanul.hakim@uts.ac.id

\begin{tabular}{ll}
\hline \multirow{2}{*}{$\begin{array}{l}\text { Diterima : } \\
\text { Bulan Juni 2021 }\end{array}$} & $\begin{array}{l}\text { Dividen suatu perusahaan selalu menjadi perhatian bagi pemegang saham untuk } \\
\text { berinvestasi. Informasi-informasi mengenai keadaan perusahaan dapat dilihat dalam } \\
\text { laporan keuangan. Penelitian ini bertujuan untuk menguji pengaruh Managerial }\end{array}$ \\
& $\begin{array}{l}\text { Ownership, Return On Equity dan Free Cash Flow terhadap Dividend Payout Ratio pada } \\
\text { Diterbitkan : }\end{array}$ \\
pulan Juli 2021 & $\begin{array}{l}\text { Menurut sartono, dividen adalah keuntungan yang diperoleh perusahaan dan dibagikan } \\
\text { kepada pemegang saham. Keputusan mengenai besarnya dividen akan ditentukan dalam }\end{array}$ \\
Keyword : & Rapat Umum Pemegang Saham (RUPS). Hasil dari penelitian ini menunjukkan bahwa \\
Dividend Payout & Managerial Ownership berpengaruh positif dan signifikan terhadap Dividend Payout \\
Ratio, Managerial & Ratio. Return On Equity berpengaruh negatif dan tidak signifikan terhadap Dividend \\
Ownership, Free & Payout Ratio dan Free Cash Flow berpengaruh positif dan tidak signifikan terhadap \\
Cash Flow dan & Dividend Payout Ratio.
\end{tabular}

Return On Equity

\section{PENDAHULUAN}

Perusahaan membutuhkan modal/dana untuk menunjang kegiatan perusahaan. Dana tersebut dapat diperoleh dari investasi. Laporan keuangan merupakan dokumen yang dapat menjelaskan mengenai informasi dan kinerja keuangan suatu perusahaan pada waktu tertentu. Menganalisis laporan keuangan tersebut digunakan investor untuk menilai baik tidaknya investasi yang dilakukan.

Perusahaan manufaktur merupakan perusahaan dengan sektor terbesar dan paling diminati investor di Bursa Efek Indonesia (Hadya, Begawati dan Yusra (2017). Perusahaan manufaktur dalam mengelola laba/keuntungan yang diperoleh perusahaan tidak selalu membagikannya sebagai dividen kepada pemegang saham, akan tetapi terkadang memilih laba ditahan. Jumlah dividen yang dibagikan juga tidak selalu tetap, akan tetapi naik-turun (Janavi, 2017). Laba yang tidak dibagikan kepada pemegang saham di investasikan kembali untuk kegiatan-kegiatan perusahaan yang lebih menguntungkan.

Pada tahun 2010-2019 hanya 30 perusahaan yang membagikan dividennya secara berturut-turut dari keseluruhan perusahaan manufaktur yang terdaftar di BEI sejak periode 2010-2019 yang berjumlah 122 perusahaan. Signaling Theory dari Modigliani-Miller mengatakan bahwa pembayaran dividen dianggap sinyal positif oleh investor dengan arti perusahaan akan mengalami pertumbuhan dimasa yang akan datang.

Keputusan mengenai dividen ini penting karena menyangkut nilai perusahaan yang dapat dilihat pada harga saham (Jhon dan Muthusamy,
2010). Namun, dalam pembuatan keputusan ini, sering terjadi konflik karena adanya perbedaan kepentingan antara pemegang saham dan manajer. Dalam meminimalisir konflik seperti ini, pihak perusahaan menciptakan suatu pengawasan yang membutuhkan biaya. Biaya yang dikeluarkan oleh pemegang saham (principal) untuk memonitoring manajer (agent) disebut Agency cost. Selain untuk mengurangi konflik, pengawasan ini ditujukan kepada manajer agar bertindak sesuai keinginan investor. Salah satu cara untuk melihat pengaruh agency cost terhadap rasio pembayaran dividen yaitu dengan menggunakan Managerial Ownership sebagai proksi dari Agency Cost.

Menurut Rohiman dan Rahayu (2015) Managerial Ownership (Kepemilikan Manajerial) adalah posisi dimana manajer tidak hanya sebagai agen akan tetapi sebagai pemegang saham juga, karena manajer memiliki sejumlah saham dalam perusahaan. Inilah yang membuat penelitian ini menjadi menarik. Saat manajer hanya sebagai agen, ada kemungkinan manajer akan patuh terhadap perintah prinsipalnya dan akan bertindak sesuai dengan tujuan yang diharapkan pemegang saham. Akan tetapi saat manajer juga sebagai pemegang saham, akan ada perbedaan mengenai keputusan yang akan diambil.

Beberapa beberapa penelitian sebelumnya juga menggunakan Managerial Ownership sebagai variabel penelitiannya. Seperti Indriani, Endang dan Purwanto (2016) dalam penelitiannya tentang Pengaruh Kepemilikan Manajerial Terhadap Kebijakan Dividen Pada Perusahaan Manufaktur 
Yang Terdaftar Di Bursa Efek Indonesia Tahun 20122014 menunjukkan bahwa kepemilikan manajerial berpengaruh positif dan signifikan terhadap kebijakan dividen. Karena hasil dalam penelitian-penelitian sebelumnya masih tidak konsisten serta sampel yang digunakan dinilai masih kurang dapat mewakili untuk mengetahui pengaruh kepemilikan manajerial terhadap Dividend Payout Ratio (DPR), peneliti ingin menguji lebih lanjut dengan memperbanyak sampel dan data perusahaan manufaktur.

Kebijakan deviden juga tentu akan melihat ketersediaan kas perusahaan. Karena dalam pembagian cash dividen, manajer hanya dapat menggunakan kas yang tersedia saat itu. Kas ini dapat kita lihat pada pos Free Cash Flow. Prasetio dan Suryono (2016) mengartikan free cash flow sebagai airan kas berupa dividen yang tersedia untuk dibagikan kepada pemegang saham. Lucyanda dan Lilyana (2012) dalam penelitian mereka menunjukkan bahwa Free Cash Flow secara positif berpengaruh terhadap DPR. Dengan adanya aliran kas bebas dalam perusahaan dapat menjadi tambahan dana untuk kegiatan perusahaan. Diduga perusahaan yang mempunyai aliran kas bebas yang tinggi akan lebih terjamin keberlangsungan usahanya. Maka pada saat yang bersamaan, FCF juga dapat dialokasikan untuk pembayaran dividen. Jika FCF dibagikan sebagai dividen, jumlah dividen yang akan diterima oleh pemegang saham akan bertambah. Kemudian faktor lain yang mempengaruhi Dividend Payout Ratio adalah profitablititas atau dalam hal ini diproksikan oleh Return on Equity (ROE). Dalam penelitian Lioew, Murni dan Mandagie (2014) menunjukkan bahwa ROE berpengaruh positif tidak signifikan terhadap Dividend Payout Ratio (DPR). ROE dapat menggambarkan seberapa cepat modal perusahaan akan kembali setelah dialokasikan kepada berbagai hal. Oleh karena itu, peneliti ingin meneliti kembali pengaruh dari Return On Equity terhadap Dividend Payout Ratio.

Dari penjelasan latar belakang, dapat kita lihat bahwa adanya permasalahan yang terjadi dalam perusahaan terkait variabel yang digunakan serta beberapa penelitian sebelumnya memiliki hasil yang tidak konsisten. Untuk itu diperlukan penelitian lebih lanjut mengenai faktor apa saja yang berpengaruh terhadap DPR. Terlebih lagi penelitian dilakukan pada perusahaan manufaktur yang sudah go public. Karena jumlah perusahaan pada sektor ini paling banyak dibandingkan sektor lain dan dikatakan penelitian sebelumnya sektor ini banyak membagikan dividen kepada investornya. Karena itu peneliti memilih sektor ini sebagai objek penelitian. Dengan begitu, judul penelitian ini adalah "PENGARUH AGENCY COST, RETURN ON EQUITY (ROE) DAN FREE CASH FLOW (FCF) TERHADAP DIVIDEND PAYOUT RATIO PADA PERUSAHAAN MANUFAKTUR YANG TERDAFTAR DI BURSA EFEK PERIODE 2010-2019”.

\section{LANDASAN TEORI}

\section{Dividend policy dan Dividend Payout Ratio}

Sartono (2011), kebijakan deviden adalah keputusan apakah laba akan dibagikan sebagai dividen kepada pemegang saham atau laba akan ditahan dan digunakan untuk pembiayaan investasi perusahaan di masa yang akan datang. Untuk mengetahui besarnya dividen yang akan dibagikan, dapat menggunakan rasio pembayaran dividen (Dividend Payout Ratio).

\section{Managerial Ownership dan Agency Cost}

Managerial Ownership atau Kepemilikan Manajerial merupakan keadaan dimana pihak manajemen adalah sebagai pemegang saham dan ikut serta dalam pengambilan keputusan (Tahu, 2018). Persamaan untuk managerial ownership (Kepemilikan manajerial) adalah sebagai berikut.

$$
\text { MOWN }=\frac{\begin{array}{c}
\text { Jumlah saham direksi dan } \\
\text { saham komisaris }
\end{array}}{\text { Saham yang beredar }}
$$

\section{Agency Cost}

Agency cost adalah biaya konflik atas kepentingan yang ada antara pemegang saham dan manajemen (Ross et al., 2009).

\section{Free Cash Flow Theory}

Free Cash Flow atau Aliran Kas Bebas didefinisikan oleh Jensen (1986) sebagai sisa kas dari seluruh pendanaan setelah dialokasikan kegiatan operasinal dan kegiatan lainnya yang akan menghasilkan NPV (Net Present Value) positif yang didiskontokan kepada tingkat biaya modal relevan. Bentuk dasar dari Free Cash Flow adalah sebagai berikut.

$$
\mathrm{FCF}=\frac{\begin{array}{c}
\text { Arus Kas Dari Operasi- (Pengeluaran Modal }+ \\
\text { Net Working Capital) }
\end{array}}{\text { Total Asset }}
$$

Net working capital $=$ aset lancar - kewajiban lancar

Keterangan :

FCF : Free Cash Flow (Aliran Kas Bebas

Net Working Capital : modal kerja bersih

Total Asset : seluruh asset dari asset lancar dan asset tetap

\section{Return On Equity (ROE)}

Menurut Kasmir (2014) Return On Equity adalah perbandingan antara laba bersih dengan modal inti perusahaan. ROE adalah salah satu alat/rasio yang dapat mengukur seberapa besar tingkat pengembalian dari ekuitas biasa. Adapun bentuk dasar dari Return on Equity adalah sebagai berikut :

$$
\mathrm{ROE}=\frac{\text { laba bersih }}{\text { Ekuitas pemegang saham }}
$$

\section{METODE PENELITIAN}

Metode penelitian yang digunakan dalam penelitian ini adalah metode penelitian kuantitatif 
dengan pendekatan asosiatif yang berguna untuk menjelaskan hubungan antara variabel-variabel dalam penelitian. Data dalam penelitian ini merupakan data sekunder yang diperoleh dari laporan keuangan perusahaan manufaktur yang terdaftar di BEI tahun 2010 sampai 2019. Sumber data adalah website resmi Bursa Efek Indonersia (www.idx.co.id ), website Bursa Efek Jakarta dan Indonesia (www.idnfinancials.com ) dan juga website perusahaan-perusahaan yang sudah go public.

Populasi dalam penelitian ini adalah 1) seluruh perusahaan manufaktur yang sudah terdaftar di BEI sejak periode 2010-2019, 2) perusahaan yang membagikan dividen secara berturut-turut dari tahun 2010 sampai 2019 dan 3) perusahaan yang manajemennya memiliki saham dalam perusahaan tersebut. Kemudian sampel Sampel dalam penelitian ini sebanyak 16 perusahaan yang diperoleh dengan teknik sampling jenuh. Menurut Sugiyono (2014) sampling jenuh adalah penentuan sampel bila semua anggota populasi dijadikan sampel penelitian.

\section{Teknis Analisis}

Dalam penelitian ini pengujian hipotesis akan menggunakan Regresi Linier Berganda dengan Model Data Panel Pooled Least Square. Penelitian ini juga menggunakan SPSS dan Eviews untuk menguji variable. Persamaan :

$$
\mathrm{Y}_{i t}=\alpha+\beta_{1} \mathrm{X}_{1 i t}+\beta_{2} \mathrm{X}_{2 \mathrm{it}}+\beta_{3} \mathrm{X}_{3 i t}+\varepsilon_{i t}
$$

\section{HASIL DAN PEMBAHASAN}

\section{Hasil Uji Asumsi Klasik}

a) Uji Normalitas

Uji normalitas bertujuan untuk menguji apakah ada variabel pengganggu berdistribusi normal dalam model regresi. Untuk mengetahui data terdistribusi normal atau tidak, penelitian ini menggunakan atau JB test. Uji Jargue-Bera memiliki ketentuan jika nilai probabilitas lebih besar dari 0,05 maka data berdistribusi normal dan sebaliknya jika nilai probabilitas lebih kecil dari 0,05 maka data tidak berdistribusi normal (Ghozali, 2018). Hasil dari uji normalitas adalah sebagai berikut:

Tabel 4.1 Hasil Uji Normalitas

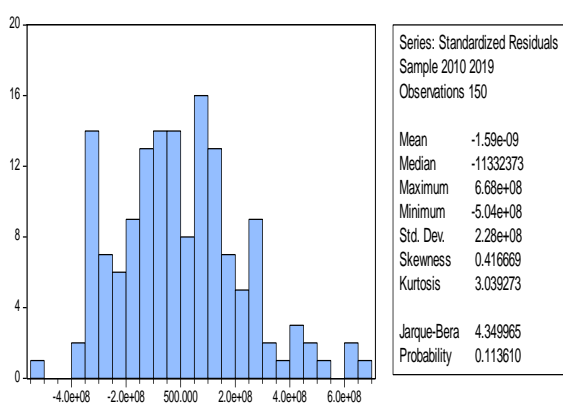

Sumber : output Eviews 9, 2021

Berdasarkan Tabel 4.1 diketahui bahwa jumlah data sampel adalah 150 data yang berasal dari 16 perusahaan dengan rentang waktu 10 tahun mulai dari tahun 2010 sampai dengan 2019. Nilai probabilitas sebesar 0.113610 yang berarti bahwa nilai probabilitas lebih besar dari 0.05 , sehingga dapat disimpulkan bahwa data terdistribusi normal.

b) Uji Multikolinieritas

Uji multikolinieritas memiliki tujuan untuk menguji apakah terdapat korelasi antar variabel independen dalam model regresi. Untuk mendeteksi ada atau tidaknya kolerasi dapat dilihat dari nilai antar variabel bebas. Pengambilan keputusan adalah jika nilai kolerasi kurang dari 0,8 maka tidak terjadi multikolinieritas pada variabel bebas. Hasil uji multikolinieritas adalah sebagai berikut.

Tabel 4.2 Hasil Uji Multikolinieritas

\begin{tabular}{|c|c|c|c|}
\hline & MOWN & ROE & FCF \\
\hline MOWN & 1.000000 & 0.038026 & -0.003482 \\
\hline ROE & 0.038026 & 1.000000 & -0.088228 \\
\hline FCF & -0.003482 & -0.088228 & 1.000000 \\
\hline
\end{tabular}

Sumber : output Eviews 9, 2021

Berdasarkan Tabel 4.2 diketahui bahwa nilai kolerasi antar variabel bebas (0.038026, $0.003482,-0.088228$ ) kurang dari 0.8. Dengan begitu kesimpulannya tidak terdapat multikolinieritas.

a) Uji Heteroskedastisitas

Uji Heterokedastisitas merupakan pengujian yang bertujuan untuk mengetahui apakah terjadi ketidaksamaan varians dari variabel suatu pengamatan ke pengamatan lain. Cara untuk mendeteksi ada atau tidaknya gejala heterokedastisitas dalam penelitian ini menggunakan uji White. Pengambilan keputusan adalah jika $C^{2}$ hitung $<C 2$ tabel, maka model estimasi terbebas dari heterokedastisitas. Sebaliknya jika $C^{2}$ hitung $>C^{2}$ tabel maka model estimasi terjadi heterokedastisitas (Ghozali, 2018).

\section{Tabel 4.3 Hasil Uji Heteroskedastisitas}

\begin{tabular}{|l|r|}
\hline$C^{2}$ hitung & 0.9 \\
\hline$C^{2}$ tabel & 5.991 \\
\hline
\end{tabular}

Berdasarkan Tabel 4.3 hasil White test diketahui bahwa $C^{2}$ hitung $<C 2$ tabel itu membuktikan bahwa tidak terjadi heteroskedastisitas.

\section{Uji Pemilihan Model}

Dalam regresi data panel terdapat tiga model yang dapat digunakan dalam mengolah data. Untuk mengetahui model yang paling tepat, penelitian ini akan menggunakan tiga metode pemilihan model. Yaitu uji chow, uji hausman dan uji Lagrange Multiplier. 
a. Hasil Chow Test

Uji Chow dilakukan dalam menguji model yang paling tepat antara model Pooled Least Square atau model Fixed Effect. Pengambilan keputusannya adalah jika nilai probability pada cross section Chi-Square lebih besar dari alpha $(\alpha)$, maka model yang paling tepat adalah model Pooled Least Square dan sebaliknya jika nilai probability pada cross section Chi-Square lebih kecil dari alpha $(\alpha)$ maka model yang paling tepat adalah Fixed Effect Model (Sakti, 2018).

\begin{tabular}{lrrrr}
\multicolumn{5}{c}{ Tabel 4.4 } \\
Hasil Uji Chow & & \\
\multirow{4}{4}{} & Statistic & d.f. & Prob. \\
Effects Test & 0.884583 & $(14,132)$ & 0.5769 \\
\hline \hline Cross-section F & 13.451340 & 14 & 0.4913 \\
Cross-section Chi-square & & & \\
\hline \hline
\end{tabular}

Zumber; output Eviews 9, 2021

Hasil uji chow pada tabel 4.4 menunjukkan bahwa cross section Chi-Square lebih besar dari alpha $(\alpha)$, yakni $0.4913<0,05$ sehingga H0 diterima. Jadi model yang paling tepat adalah PooledLeast Square.

\section{b. Hasil Hausman Test}

Berdasarkan hasil chow test model yang tepat adalah fixed effect sehingga dilanjutkan dengan hausman test untuk menentukan apakah model fixed effect atau random effect yang tepat digunakan.

Tabel 4.5

Hasil Uji Hausman

\begin{tabular}{lrrr}
\hline \hline Test Summary & Chi-Sq. Statistic & Chi-Sq. d.f. & Prob. \\
\hline \hline Cross-section random & 1.865909 & 3 & 0.6007 \\
\hline \hline
\end{tabular}

Sumber: output Eviews 9, 2021

Berdasarkan pada tabel 4.5 hasil hausman test menunjukkan nilai probabilitas pada Crosssection random 0.6007 yang berarti probabilitas Cross-section random lebih besar dari alpha (0.05). Kesimpulan pada uji hausman ini model yang paling tepat adalah Random Effect Model.

\section{c. Hasil Lagrange Multiplier}

Lagrange Multiplier Test adalah pengujian untuk memilih apakah model yang digunakan common effect atau random effect. Dimana model pooled least square sebagai $\mathrm{H} 0$ dan $\mathrm{H} 1$ adalah model random effect.

Uji LM ini didasarkan pada probability Breusch-Pagan, jika nilai probability BreuschPagan kurang dari nilai alpha maka Ho ditolak yang berarti estimasi yang tepat untuk regresi data panel adalah model random effect dan jika nilai probability Breusch-Pagan kurang dari nilai alpha maka $\mathrm{H} 1$ ditolak yang berarti estimasi yang tepat untuk regresi data panel adalah model pooled least square.

Tabel 4.6

Hasil Uji Lagrange Multiplier

Lagrange Multiplier Tests for Random Effects

Null hypotheses: No effects

Alternative hypotheses: Two-sided (Breusch-Pagan) and one-sided (all others) alternatives

\begin{tabular}{lccc}
\hline \hline & \multicolumn{3}{c}{ Test Hypothesis } \\
& Cross-section & Time & Both \\
\hline \hline Breusch-Pagan & 0.267007 & 5.913768 & 6.180775 \\
& $(0.6053)$ & $(0.0150)$ & $(0.0129)$
\end{tabular}

Sumber: output Eviews 9, 2021

Berdasarkanhasil uji LM diatas menunjukkan bahwaprobability Breusch-Pagan lebih dari alpha, yakni $0.6053>0.05$. Ini membuktikan bahwa model terbaik yang digunakan PooledLeast Square.

\section{A. Model Regresi Data Panel}

Berdasarkan hasil uji chow, uji hausman dan uji lagrange multiplier bahwa metode yang tepat digunakan dalam penelitian ini adalah PooledLeast Square. Berikut hasil regresi data panel model pooled least square.

\section{Tabel 4.7 Pooled Least Square}

\begin{tabular}{|c|c|c|c|c|}
\hline \multicolumn{5}{|c|}{$\begin{array}{l}\text { Dependent Variable: DPR } \\
\text { Method: Panel Least Squares } \\
\text { Date: 02/25/21 Time: } 13: 00 \\
\text { Sample: } 20102019 \\
\text { Periods included: } 10 \\
\text { Cross-sections included: } 16 \\
\text { Total panel (balanced) observations: } 150\end{array}$} \\
\hline Variable & Coefficient & Std. Error & t-Statistic & Prob. \\
\hline MOWN & 1.334099 & 0608741 & 2191572 & 00300 \\
\hline ROE & -13.47426 & 7.713748 & -1.746785 & 0.0828 \\
\hline FCF & 21.75772 & 13.13274 & 1.656754 & 0.0997 \\
\hline $\mathrm{C}$ & $3.71 \mathrm{E}+08$ & 30013882 & 12.36199 & 0.0000 \\
\hline R-squared & 0.069191 & \multicolumn{2}{|c|}{ Mean dependent var } & $3.55 \mathrm{E}+08$ \\
\hline Adjusted R-squared & 0.050065 & \multicolumn{2}{|c|}{ S.D. dependent var } & $2.36 \mathrm{E}+08$ \\
\hline S.E. of regression & $2.30 E+08$ & \multicolumn{2}{|c|}{ Akaike info criterion } & 41.37439 \\
\hline Sum squared resid & $7.75 \mathrm{E}+18$ & \multicolumn{2}{|c|}{ Schwarz criterion } & 41.45468 \\
\hline Log likelihood & -3099.079 & \multicolumn{2}{|c|}{ Hannan-Quinn criter. } & 41.40701 \\
\hline F-statistic & 3.617618 & \multirow{2}{*}{\multicolumn{2}{|c|}{ Durbin-Watson stat }} & 1.632640 \\
\hline $\operatorname{Prob}($ F-statistic) & 0.014734 & & & \\
\hline
\end{tabular}

Sumber: output Eviews 9,2021

Tabel 4.7 merupakan regresi antara managerial ownership, return on equity dan free cash flow terhadap dividend payout ratio. Dari regresi tersebut diperoleh persamaan sebagai berikut. 
$\mathrm{DPR}=3.77 \mathrm{E}+08+1.334099(\mathrm{MOWN})-$ $13.47426(\mathrm{ROE})+21.75772(\mathrm{FCF})+\varepsilon$

Persamaan regresi di atas memiliki arti sebagai berikut:

1. Berdasarkan hasil uji regresi nilai konstanta sebesar 3.77E+08, artinya jika nilai Managerial Ownership, Return On Equity dan Free Cash Flow diabaikan. Maka Dividend Payout Ratio dipengaruhi sebesar $3,77 \%$.

2. Managerial Ownership mempengaruhi Dividend Payout Ratio sebesar 1.334099 yang artinya setiap kenaikan Managerial Ownership sebesar 1\% maka akan akan meningkatkan Dividend Payout Ratio sebesar $1.33 \%$.

3. Return On Equity mempengaruhi Dividend Payout Ratio sebesar -13.47426 yang artinya setiap Return On Equity mengalami kenaikan sebesar $1 \%$ maka akan mengurangi Dividend Payout Ratio sebesar $13.47 \%$.

4. Free Cash Flow mempengaruhi Dividend Payout Ratio sebesar 21.75772 yang artinya setiap Free Cash Flow mengalami kenaikan sebesar $1 \%$ maka akan meningkatkan Dividend Payout Ratio sebesar $21.75 \%$.

\section{B. Uji Hipotesis}

Analisis regresi linier berganda dalam penelitian ini menggunakan model Pooled Least Square. Model ini dipilih setelah melalui uji chow, uji hausman dan uji lagrange multiplier. Pengujian hipotesis pada penelitian ini dilakukan dengan tingkat signifikansi $\quad \alpha=0.05 \quad(5 \%)$. Hipotesis penelitian adalah:

$\mathrm{H}_{1}$ : Managerial Ownership berpengaruh negative terhadap Dividend Payout Ratio (DPR)

$\mathrm{H}_{2}$ : ROE berpengaruh positif terhadap Dividend Payout Ratio (DPR)

$\mathrm{H}_{3}$ : Free Cash Flow berpengaruh positif terhadap Dividend Payout Ratio (DPR)

$\mathrm{H}_{4}$ : Managerial Ownership, Return On Equity dan Free Cash Flow berpengaruh secara simultan terhadap Dividend Payout Ratio (DPR)

\section{a) Uji t (Uji Parsial)}

Uji parsial dilakukan untuk mengetahui apakah setiap variabel independen yang membentuk model regresi mempengaruhi variabel dependen secara parsial atau tidak. Hasil uji $\mathrm{t}$ adalah sebagai berikut.

1. Pengaruh Managerial Ownership terhadap Dividend Payout Ratio
Berdasarkan hasil regresi pada tabel 4.7 Agency Cost yang diproksikan Managerial Ownership memiliki nilai probabilitas 0.0300 yang berarti lebih kecil dari alpha, yakni $0.0300<0,05$. Hasil tersebut menunjukkan bahwa Managerial Ownership berpengaruh positif dan signifikan terhadap Dividend Payout Ratio. Dengan kata lain $\mathrm{H}_{0}$ ditolak dan $\mathrm{H}_{1}$ diterima.

2. Pengaruh Return On Equity terhadap Dividend Payout Ratio

Hasil regresi menunjukkan nilai probabilitas Return On Equity sebesar 0.0828 yang berarti lebih besar dari alpha, yakni $0.0828>0,05$ dengan koefisien -13.47426. Hasil tersebut menunjukkan bahwa Return On Equity berpengaruh negatif dan tidak signifikan terhadap Dividend Payout Ratio $\left(\mathrm{H}_{1}\right.$ ditolak dan $\mathrm{H}_{0}$ diterima).

3. Pengaruh Free Cash Flow terhadap dividend payout ratio

Free Cash Flow pada hasil regresi memiliki nilai probabilitas 0,0997 yang berarti lebih besar dari alpha, yakni $0.0997>0,05$. Hasil tersebut menunjukkan bahwa Free Cash Flow berpengaruh positif dan tidak signifikan terhadap Dividend Payout Ratio. Oleh karena itu $\mathrm{H}_{0}$ diterima dan $\mathrm{H}_{1}$ ditolak.

Dengan begitu dapat disimpulkan, setiap variabel pada penelitian ini berpengaruh terhadap variabel dependennya.

\section{Uji F (Uji Simultan)}

Uji F dilakukan untuk mengetahui apakah secara bersamaan variabel independen mempengaruhi variabel dependen. Dikatakan berpengaruh signifikan jika nilai $F$-statistic lebih kecil alpha $(\alpha) 0.05$.

$\mathrm{H}_{0}=$ Managerial Ownership, Return On Equity dan Free Cash Flow secara simultan tidak berpengaruh secara signifikan terhadap Dividend Payout Ratio

$\mathrm{H}_{1}=$ Managerial Ownership, Return On Equity dan Free Cash Flow secara simultan berpengaruh secara signifikan terhadap Dividend Payout Ratio

Berdasarkan hasil regresi pada tabel 4.7 nilai prob ( $F$-statistic) sebesar 0.014734 yang berarti lebih kecil dari 0.05 . Dengan begitu, $\mathrm{H}_{1}$ diterima atau Managerial Ownership, Return On Equity dan Free Cash Flow secara simultan berpengaruh secara signifikan terhadap Dividend Payout Ratio.

\section{Koefisien Determinasi $\left(R^{2}\right)$}

Koefisien Determinasi $\left(R^{2}\right)$ digunakan untuk mengukur kemampuan model untuk mengukur variasi variabel dependen. Nilai 
koefisien determinasi adalah antara 0-1. Semakin mendekati satu berarti variabel penelitian mampu memberikan semua informasi yang diperlukan dalam menjelaskan variabel dependen. Sedangkan jika nilai koefisien determinasi semakin mendekati nol artinya variabel penelitian hanya mampu memberikan informasi tentang variabel dependen secara terbatas (Ghozali, 2018). Berdasarkan hasil pada tabel 4.7 nilai Adjusted R-square diketahuisebesar 0.050065, yang menjelaskan bahwa Managerial Ownership, Return On Equity dan Free Cash Flow mampu menjelaskan informasi mengenai Dividend Payout Ratio sebesar 5\% dan sisanya sebesar 95\% dijelaskan oleh faktor lain diluar penelitian ini.

\section{Pembahasan}

Setelah melakukan analisis data dalam penelitian, tahap selanjutnya adalah memaparkan hasil dari penelitian:

1. Penelitian ini menggunakan regresi liniear berganda dengan model data panel. Cross section pada penelitian ini berjumlah 16 dan time series 10 tahun. Dimana data/observasi penelitian awalnya berjumlah 160 data. Namun, karena adanya data outlier maka 10 data harus dihilangkan. Berikut daftar data outlier yang dihapus.

1. Perusahaan INDF sebanyak 4 data yakni data tahun 2016, 2017, 2018 dan 2019.

2. Perusahaan UNIC sebanyak 2 data yakni data tahun 2014 dan 2015

3. Perusahaan UNVR sebanyak 4 data yakni data tahun 2011, 2012, 2014 dan 2018.

2. Managerial Ownership berpengaruh positif dan signifikan terhadap Dividend Payout Ratio

Berdasarkan pada hasil uji hipotesis yang telah dilakukan. Uji $\mathrm{T}$ pada variabel Managerial Ownership terhadap Dividend Payout Ratio pada perusahaan manufaktur di BEI periode 2010-2019 menunjukkan pengaruh positif dan signifikan. Artinya ketika persentase kepemilikan saham oleh manajerial semakin tinggi, maka jumlah dividen yang dibagikan semakin tinggi. Hasil ini sesuai dengan teori dari Rozeff tahun 1982 yang mengemukakan bahwa ketika ada kepemilikan manajerial yang tinggi dalam perusahaan, maka akan cenderung menetapkan dividen yang tinggi dan sebaliknya. Hal ini dapat dilihat pada perusahaan ASII tahun 2017 dan 2018 Pada tahun 2017 saham manajerialnya sebesar 16.190.000 dengan dividen sebesar 7.489.457.330.900. Kemudian tahun 2018 saham manajerial meningkat menjadi 20.111.900 dengan dividen sebesar 8.668.743.233.868. Lebih lanjut lagi dijelaskan bahwa kepemilikan saham merupakan insentif bagi manajer untuk meningkatkan kinerja perusahaan. Dimana dana untuk mendanai operasional perusahaan diperoleh dari hutang.

Managerial ownership yang tinggi dalam perusahaan juga secara jelas akan mendapatkan dividen yang lebih besar. Penelitian ini didukung oleh penelitian Setiawan et al., (2016) yang menunjukkan hasil Managerial Ownership berpengaruh positif dan signifikan terhadap Dividend Payout Ratio

3. Return On Equity berpengaruh negatif dan tidak signifikan terhadap Dividend Payout Ratio

Berdasarkan pada hasil uji hipotesis yang telah dilakukan. Uji $\mathrm{T}$ pada variabel Return On Equity terhadap Dividend Payout Ratio perusahaan manufaktur di BEI periode 2010-2019 menunjukkan pengaruh negatif dan tidak signifikan. Artinya ketika rasio tingkat pengembalian modal (ROE) meningkat, rasio pembayaran dividen akan menurun. Hal ini berarti bahwa laba bersih dari ekuitas pada objek penelitian tidak semua dialokasikan untuk pembayaran dividen, akan tetapi menjadi laba ditahan. Dibuktikan dengan data alokasi laba bersih pada 16 perusahaan objek penelitian sebagai berikut.

Tabel 4.8

Pembagian Laba Bersi

\begin{tabular}{|c|c|c|c|}
\hline Perusahaan & Periode & Dividen & Laba Ditahan \\
\hline \multirow[t]{5}{*}{ ASII } & 2015 & 7.165 .588 .905 .780 & 8.447 .411 .094 .220 \\
\hline & 2016 & 6.801 .236 .927 .520 & 11.500 .763 .072 .480 \\
\hline & 2017 & 7.489 .457 .330 .900 & 15.631 .542 .669 .100 \\
\hline & 2018 & 8.668 .743 .233 .868 & 18.703 .256 .766 .132 \\
\hline & 2019 & 8.663 .480 .371 .960 & 17.957 .519 .628 .040 \\
\hline \multirow[t]{5}{*}{ AUTO } & 2015 & 130.132 .791 .000 & 192.568 .209 .000 \\
\hline & 2016 & 43.377 .597 .000 & 440.043 .403 .000 \\
\hline & 2017 & 159.051 .189 .000 & 388.729 .811 .000 \\
\hline & 2018 & 245.806 .383 .000 & 434.994 .617 .000 \\
\hline & 2019 & 294.003 .713 .000 & 522.967 .287 .000 \\
\hline \multirow[t]{5}{*}{ GGRM } & 2015 & 5.002 .628 .800 .000 & 1.450 .205 .200 .000 \\
\hline & 2016 & 5.002 .628 .800 .000 & 1.670 .053 .200 .000 \\
\hline & 2017 & 5.002 .628 .800 .000 & 2.752 .718 .200 .000 \\
\hline & 2018 & 5.002 .628 .800 .000 & 5.878 .075 .200 .000 \\
\hline & 2019 & 5.002 .628 .800 .000 & 2.790 .439 .200 .000 \\
\hline \multirow[t]{5}{*}{$\mathrm{INDF}$} & 2015 & 1.475 .111 .652 .000 & 3.392 .235 .348 .000 \\
\hline & 2016 & 2.063 .400 .227 .500 & 2.920 .904 .772 .500 \\
\hline & 2017 & 2.080 .961 .080 .500 & 2.958 .106 .919 .500 \\
\hline & 2018 & 2.072 .180 .654 .000 & 4.278 .6007 .346 .000 \\
\hline & 2019 & 2.440 .958 .567 .000 & 4.147 .703 .433 .000 \\
\hline \multirow[t]{5}{*}{ IKBI } & 2015 & 8.498 .441 .160 & 9.394 .200 .000 \\
\hline & 2016 & 23.341 .680 .000 & 33.003 .819 .936 \\
\hline & 2017 & 6.120 .000 .000 & 11.276 .043 .874 \\
\hline & 2018 & 10.758 .960 .000 & 21.039 .794 .277 \\
\hline & 2019 & 13.953 .600 .000 & 19.288 .326 .225 \\
\hline \multirow[t]{5}{*}{ KAEF } & 2015 & 46.875 .760 .000 & 206.096 .746 .074 \\
\hline & 2016 & 53.485 .020 .000 & 213.929 .072 .891 \\
\hline & 2017 & 98.083 .640 .000 & 228.684 .609 .091 \\
\hline & 2018 & 83.198 .920 .000 & 408.367 .017 .778 \\
\hline & 2019 & 25.447 .876 .760 & 101.792 .143 .240 \\
\hline
\end{tabular}




\begin{tabular}{|c|c|c|c|}
\hline \multirow{5}{*}{ KBLM } & 2015 & 3.360 .000 .000 & 8.427 .506 .863 \\
\hline & 2016 & 5.600 .000 .000 & 15.645 .022 .916 \\
\hline & 2017 & 11.200 .000 .000 & 32.794 .949 .645 \\
\hline & 2018 & 11.200 .000 .000 & 29.475.096.628 \\
\hline & 2019 & 11.200 .000 .000 & 27.448 .269 .147 \\
\hline \multirow{5}{*}{ LION } & 2015 & 2.080 .640 .000 & 47.391 .586 .776 \\
\hline & 2016 & 2.080 .640 .000 & 34.729 .360 .000 \\
\hline & 2017 & 780.240 .000 & 8.502 .760 .000 \\
\hline & 2018 & 520.160 .000 & 14.159 .840 .000 \\
\hline & 2019 & 520.160 .000 & 8.744 .471 .999 \\
\hline \multirow{5}{*}{ SCCO } & 2015 & 46.256 .265 .000 & 106.286 .785 .307 \\
\hline & 2016 & 61.675 .020 .000 & 278.918 .610 .534 \\
\hline & 2017 & 71.954 .190 .000 & 197.776 .108 .809 \\
\hline & 2018 & 71.954.190.000 & 182.041 .142 .656 \\
\hline & 2019 & 102.791 .700 .000 & 200.802 .222 .331 \\
\hline \multirow{5}{*}{ SMSM } & 2015 & 194.968 .260 .900 & 266.338 .739 .100 \\
\hline & 2016 & 201.553 .640 .400 & 300.638 .359 .600 \\
\hline & 2017 & 69.104 .105 .280 & 486.283 .894 .720 \\
\hline & 2018 & 334.003 .175 .520 & 299.546 .824 .480 \\
\hline & 2019 & 270.120 .771 .840 & 368.555 .228 .160 \\
\hline \multirow{5}{*}{ SKLT } & 2015 & 4.144 .443 .000 & 15.922 .348 .849 \\
\hline & 2016 & 3.453 .702 .500 & $\begin{array}{l}17.192 .418 .574 \\
\end{array}$ \\
\hline & 2017 & 4.835.183.500 & 18.135.531.848 \\
\hline & 2018 & 6.216 .664 .500 & 25.737 .466 .752 \\
\hline & 2019 & 10.361 .107 .500 & 34.582 .520 .400 \\
\hline \multirow{5}{*}{ TCID } & 2015 & 82.437 .333 .470 & 458.681 .183 .490 \\
\hline & 2016 & 82.437 .333 .470 & 68.287.029.292 \\
\hline & 2017 & 82.437 .333 .470 & 75.167 .828 .715 \\
\hline & 2018 & 84.448 .000 .140 & 112.126 .162 .045 \\
\hline & 2019 & 84.448 .000 .140 & 46.680 .652 .023 \\
\hline \multirow{5}{*}{ TRST } & 2015 & 11.274 .103 .403 & 14.040 .000 .000 \\
\hline & 2016 & 14.040 .000 .000 & 19.754 .866 .940 \\
\hline & 2017 & 14.040 .000 .000 & 24.159 .681 .742 \\
\hline & 2018 & 14.040 .000 .000 & 49.153 .899 .099 \\
\hline & 2019 & 14.040 .000 .000 & 24.871 .968 .283 \\
\hline \multirow{5}{*}{ TSPC } & 2015 & 225.000 .000 .000 & 304.218 .651 .807 \\
\hline & 2016 & 225.000 .000 .000 & 320.493 .536 .262 \\
\hline & 2017 & 180.000 .000 .000 & 377.339 .581 .996 \\
\hline & 2018 & 180.000 .000 .000 & 360.378 .145 .887 \\
\hline & 2019 & 225.000 .000 .000 & 370.154 .912 .874 \\
\hline \multirow{5}{*}{ UNIC } & 2015 & 14.833 .920 .897 & 26.449 .864 .047 \\
\hline & 2016 & 17.267.778.436 & 280.598 .557 .716 \\
\hline & 2017 & 35.266 .485 .396 & 132.990 .103 .302 \\
\hline & 2018 & 90.529 .355 .880 & 172.499 .113 .350 \\
\hline & 2019 & 44.466 .438 .108 & 116.849 .242 .177 \\
\hline \multirow{5}{*}{ UNVR } & 2015 & 5.844 .580 .000 .000 & 7.225 .000 .000 \\
\hline & 2016 & 6.371 .050 .000 .000 & 19.622 .000 .000 \\
\hline & 2017 & 6.981 .450 .000 .000 & 23.112 .000 .000 \\
\hline & 2018 & 9.041 .550 .000 .000 & 39.637 .000 .000 \\
\hline & 2019 & 4.097 .310 .000 .000 & 3.295 .527 .000 .000 \\
\hline
\end{tabular}

Tabel 4.8 menjelaskan bahwa laba bersih pada perusahaan manufaktur di BEI sebagian besar digunakan untuk biaya operasional perusahaan. Dapat dilihat pada tabel tersebut, perusahaan ASII tahun 2015 memiliki laba bersih sebesar 15.613.000.000.000, kemudian dibagikan sebagai dividen sebesar 7.165.588.905.780 dan laba ditahan sebesar 8.447.411.094.220. Pada tahun selanjutnya 2016 laba bersih perusahaan meningkat menjadi 18.302.000.000.000 dengan dividen berkurang menjadi 6.801.236.927.520 dan laba ditahan bertambah menjadi 11.500.763.072.480. Dengan tren yang turun, itu membuktikan ROE pada penelitian ini berpengaruh negatif pada dividen. Meskipun pada beberapa tahun yang lain DPR meningkat namun peningkatan laba ditahan sangat jauh lebih besar. Dengan begitu, hasil uji hipotesis yang menunjukkan ROE akan semakin jelas terbukti. Penelitian ini didukung oleh penelitian Irwara (2017) yang menunjukkan hasil Return On Equity berpengaruh negatif dan tidak signifikan terhadap Dividend Payout Ratio.

4. Free Cash Flow berpengaruh positif dan tidak signifikan terhadap Dividend Payout Ratio

Berdasarkan uji $\mathrm{T}$ pada variabel Free Cash Flow terhadap Dividend Payout Ratio perusahaan manufaktur di BEI periode 2010-2019 menunjukkan pengaruh positif dan tidak signifikan. Artinya setiap Free Cash Flow mengalami kenaikan, maka jumlah dividen yang dibagikan akan meningkat, namun tidak signifikan. Hal ini berarti aliran kas bebas pada objek penelitian dapat digunakan untuk pembayaran dividen. Sesuai dengan yang diungkapkan Ahmed dan Javid (2008), tersedianya aliran kas bebas, maka semakin besar pula potensi untuk pembayaran dividen. Dengan hasil yang tidak signifikan, ada kemungkinan aliran kas bebas juga dapat digunakan untuk operasional perusahaan. Hasil penelitian ini didukung oleh penelitian Prasetio dan Suryono (2016) yang menunjukkan hasil Free Cash Flow berpengaruh positif terhadap Dividend Payout Ratio.

\section{Penelitian ini sesuai dengan Bird In The}

Hand Theory, dimana pemegang saham lebih menyukai dan memilih dividen tunai daripada laba ditahan karena adanya kepastian keuntungan dari investasi yang sudah mereka lakukan. Hal ini juga digambarkan dari Managerial Ownership dan Free Cash Flow yang berpengaruh positif terhadap Dividend Payout Ratio. Kemudian hasil penelitian ini sesuai dengan pengembangan hipotesis penelitian yang telah dibangun oleh peneliti yakni pada hipotesis ketiga dan keempat.

\section{PENUTUP}

\section{Kesimpulan}

Penelitian ini bertujuan untuk menguji pengaruh variabel Managerial Ownership, Return On Equity dan Free Cash Flow pada 
perusahaan manufaktur yang terdaftar di Bursa Efek Indonesia periode 2010-2019. Penelitian ini menggunakan aplikasi Eviews 9 dan SPSS dalam menganalisis data untuk menguji pengaruh antara variabel independen dan dependen. Berdasarkan hasil analisis dan pembahasan sebelumnya bisa ditarik kesimpulan sebagai berikut:

1. Hasil analisis menunjukkan bahwa Managerial Ownership berpengaruh positif dan signifikan terhadap Dividend Payout Ratio. Yang artinya semakin tinggi Managerial Ownership akan semakin tinggi Dividend Payout Ratio. Dengan nilai signifikansi sebesar 0.0300 yang berarti lebih kecil dari 0.05 (nilai $\alpha=0.05$ ). Nilai koefisien regresi sebesar 1.334099, maka dari itu hipotesis pertama yang menyatakan Managerial Ownership berpengaruh negatif terhadap Dividend Payout Ratio ditolak.

2. Hasil analisis menunjukkan bahwa Return On Equity berpengaruh negatif dan tidak signifikan terhadap Dividend Payout Ratio. Dengan nilai signifikansi sebesar 0.0828 yang berarti lebih kecil dari 0.05 (nilai $\alpha=0.05$ ). Nilai koefisien regresi sebesar -13.47426, maka dari itu hipotesis kedua yang menyatakan Return On Equity berpengaruh positif terhadap Dividend Payout Ratio ditolak

3. Hasil analisis menunjukkan bahwa Free Cash Flow berpengaruh positif dan tidak signifikan terhadap Dividend Payout Ratio. Dengan nilai signifikansi sebesar 0.0997 yang berarti lebih kecil dari 0.05 (nilai $\alpha=0.05$ ). Nilai koefisien regresi sebesar 21.75772, maka dari itu hipotesis ketiga yang menyatakan Free Cash Flow berpengaruh positif terhadap Dividend Payout Ratio diterima.

4. Managerial Ownership, Return On Equity dan Free Cash Flow secara simultan berpengaruh secara signifikan terhadap Dividend Payout Ratio.

5. Berdasarkan hasil regresi, nilai prob ( $F$ statistic) sebesar 0.014734 yang berarti lebih kecil dari 0.05. Dengan begitu, hipotesis penelitian keempat yang menyatakan Managerial Ownership, Return On Equity dan Free Cash Flow secara simultan berpengaruh terhadap Dividend Payout Ratio terima.

\section{DAFTAR PUSTAKA}

Brigham, Eugene F. and Houston, Joel F. (2011). Dasar-Dasar Manajemen Keuangan. Jakarta: Salemba Empat.

Ghozali, Imam. (2018). Analisis Multivariat dan Ekonometrika, Teori Konsep dan Aplikasi dengan Eviews 10. Semarang: UNDIP

Hadya, Rizka, Begawati, Nova dan Yusra, Irdha. (2017). Analisis efektivitas pengendalian biaya, perputaran modal kerja, dan rentabilitas ekonomi menguunakan regresi data panel. Jurnal Manajemen, Akuntansi dan Ilm Ekonomi. 1(3), 153-166.

Indriani, Wiwin, Endang, Anastasia dan Purwanto, Nanang. (2015). Pengaruh Kepemilikan Manajerial dan Kinerja Keuangan Terhadap Kebijakan Dividen Pada Perusahaan Manufaktur yang Terdaftar di BEI Tahun 2012-2014. Jurnal Riset Akuntansi. 10(10), 1-10.

John, S Franklin, and K Muthusamy. (2010). Leverage, Growth and Profitability as Determinants of Dividend Payout RatioEvidence from Indian Paper Industry. Asian Journal of Business Management Studies. 1 (1): 26-30.

Lioew, Meykel, Murni, Sri dan Mandagie, Yunita. (2014). ROA, ROE, NPM Pengaruhnya Terhadap Dividend Payout Ratio Pada Perusahaan Perbankan dan Financial Institusi yang Terdaftar di BEI periode 2010-2012. Jurnal Ekonomi dan Pembangunan, 2(2). 1406-1416.

Lucyanda, Jurica Dan Lilyana. (2012). Pengaruh Free Cash Flow dan Struktur Kepemilikan Terhadap Dividend Payout Ratio. Jurnal Dinamika Akuntansi, 4 (2), 129-138

Mnune, Dewi dan Purbawangsa, Anom. (2019). Pengaruh Profitabilitas, Leverage, Ukuran Perusahaan Dan Risiko Bisnis Terhadap Kebijakan Dividen Pada Perusahaan Manufaktur. Jurnal Manajemen, 8(5), 2862-2890.

Prasetio, Djoko Adi dan Suryono Bambang. (2016). Pengaruh Profitabilitas, Free Cash Flow, Investment Opportunity Set Terhadap Dividend Payout Ratio. Jurnal Ilmu dan Riset Akuntansi, 5(1). 1-19.

Rohiman, Oktaviani dan Rahayu, Sri. (2015). Kepemilikan Manajerial, Kepemilikan Institusional, Keijakan Dividen, dan Kebijakan Hutang, Analisis Terhadap Nilai Perusahaan Sektor Jasa yang Terdaftar di BEI periode 2009-2012. Jurnal Manajemen, 2(1), 341-348.

Ross, Stephen A., Westerfield dan Jaffe. (2009). Corporate Finance. McGraw Hill, New York : The Mc Graw-Hill Companies, Inc

Sakti, Indra. (2018). Modul Eviews 9: Analisis Regresi Data Panel Menggunakan Eviews, Jakarta: Universitas Esa Unggul

Sartono, Agus. (2011). Manajemen Keuangan. Teori dan Aplikasi. BPFE. Yogyakarta.

Sekaran, Uma dan Bougie, Roger. (2017). Metodologi Penelitian untuk BisnisPendekatan PengembanganKeahlian.Jakarta Selatan: Salemba empat. 